Yevgen Kovalov

\title{
PRODUCTION AND QUALITY OF BLAST FURNACE COKE IN UKRAINE
}

Received: May 16, 2007

\author{
Ukrainian State Research Institute for Carbochemistry UKHIN \\ 7 Vesnina Str., Kharkov 61023, Ukraine \\ nto@ukhin.org.ua
}

\begin{abstract}
This research displays the state of metallurgical coke production in Ukrainew with special attention to the raw material base for production of coke and its quality. Besides the following essay deals with the detailed analysis of preparation methods of coal charge for coking, including thermal treatment and stamp charging and formulates the main ways of upgrading coke quality considering the rational technology of coking.
\end{abstract}

Key words: coal, coal blends, coke, blast furnace coke, coke production, preheated blends, stamped blends, coke structure, blast-furnaces melting, coke reactivity

Ukraine has 56 operational coke oven batteries the total capacity of which is about $24 \mathrm{~m}$ tonnes per year of bulk coke of $6 \%$ moisture.

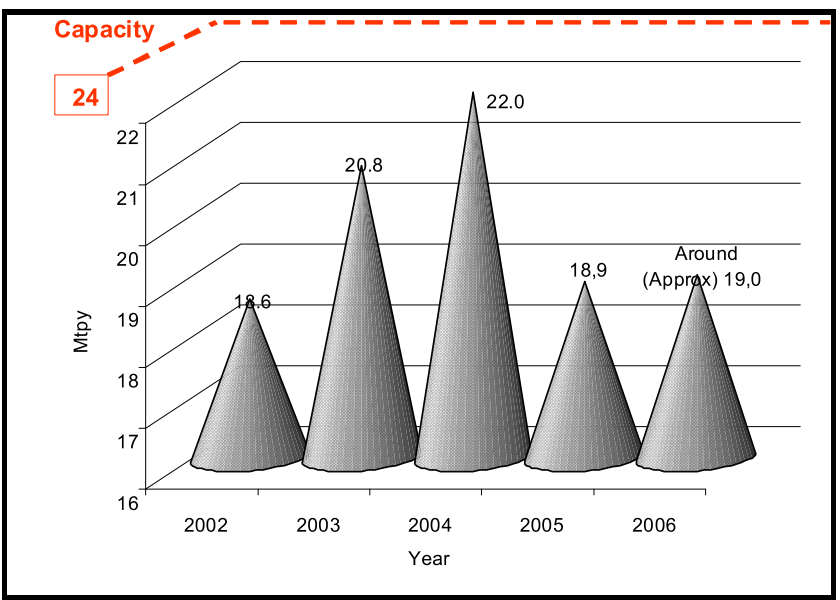

Fig. 1. Production of coke in Ukraine

The output of coke in Ukraine is determined in the first place by its consumption first of all by metallurgical plants to produce cast iron. It should be noted that after a sharp decline in production of metal products during the last years of the former Soviet Union the production of iron steadily grows in the independent Ukraine during 16 years. In 2006 the maximal level was reached for all these years $-32.7 \mathrm{~m}$ tonnes. According to the Ukrainian Association Metallurgprom, in 2007 the metallurgical plants in Ukraine will increase the production of iron to $35.5 \mathrm{~m}$ tonnes (by $7.3 \%$ ) [1].

Powerful iron and steel industry of Ukraine requires a lot of coke. Our country takes the fourth place in the world production of coke after China, Japan and Russia. For the past five years the output of coke in Ukraine, after its maximum at $22 \mathrm{~m}$ tpy in 2004 , decreased to a level of $19.2 \mathrm{~m}$ tpy in 2006 , but the contribution of the coke producers in 2006 was somewhat different compared to 2005 (Fig. 2).

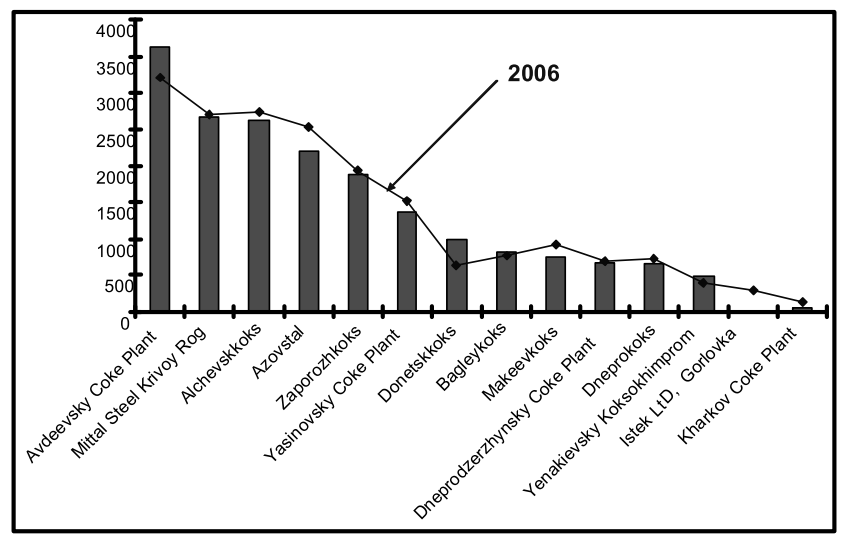

Fig. 2. Production of coke in Ukraine in 2005-2006

The reasons of such a decline, in our opinion, are as follows:

- improvement of blast furnace operation, resulting in gradual reduction of the specific coke rate (last decade this index decreased from $630 \mathrm{~kg}$ to $508.5 \mathrm{~kg}$ per tonne of hot metal);

- more stringent requirements to the quality of coke that predetermines the coke rate,

- excess of imports of coke (mainly from Russia and Poland) over its exports.

All these reasons are interconnected. They are based mainly on discrepancy in the required and real quality of coke due to the features of the available coal base at Ukrainian coke works.

Table 1 presents the properties of blends from typical Ukrainian coals compared to similar properties for the leading world coke producers. 
Properties of coal blends and main process parameters of cokemaking

\begin{tabular}{|l|c|c|}
\hline \multirow{2}{|c|}{ Indices and units of measure } & $\begin{array}{c}\text { Numerical values } \\
\text { Coal blend } \\
\text { (typical } \\
\text { coals) }\end{array}$ & $\begin{array}{c}\text { Leading } \\
\text { world } \\
\text { producers }\end{array}$ \\
\hline \multicolumn{3}{|c|}{} \\
\hline Ash $\mathrm{A}^{\mathrm{d}}, \%$ dry basis & $8.5-9.0$ & $\leq 8.5$ \\
\hline Total sulphur $\mathrm{S}_{\mathrm{t}}^{\mathrm{d}}, \%$ dry basis & $\leq 2.5$ & $\leq 1.0$ \\
\hline $\begin{array}{l}\text { Volatile matter } \mathrm{V}^{\text {daf }}, \% \text { dry ash } \\
\text { free basis }\end{array}$ & $29-32$ & $\leq 27$ \\
\hline Plastic layer y, mm & $14-18$ & $14-16$ \\
\hline Basicity of ash & $0.25-0.35$ & $\leq 0.16$ \\
\hline $\begin{array}{l}\text { Mean arbitrary vitrinite reflectance } \\
\text { index } \mathrm{R}_{\mathrm{o}}, \%\end{array}$ & $\leq 1.0$ & $\geq 1.2$ \\
\hline $\begin{array}{l}\text { Non-uniformity index of blend by } \\
\text { vitrinite rank } \sigma_{\mathrm{R}}, \%\end{array}$ & $0.25-0.35$ & 0.15 \\
\hline Carbonization parameters & $\geq 1000$ & $\geq 1000$ \\
\hline temperature, ${ }^{\circ} \mathrm{C}$ & $\leq 28$ & $\leq 24$ \\
\hline Carbonizing rate, mm/hr
\end{tabular}

The distinctive feature of typical Donbass coals (main source of coking coals for Ukraine coke works) is their genetically high level of sulphur in the first line due to pyritic sulphur [2].

Low rank coals with high volatile matter and low vitrinite reflectance prevail in the geological reserves and coals mined in Ukraine. The share of domestic high rank coking coals (mean reflectance index of vitrinite above $1.0 \%$ ) in the raw material base of the coke works in Ukraine is very insignificant. As a result, in spite of introduction of high rank coals from other coal basins (first of all from Kuznetsk in Russia), the yield of volatile matter from coal blends at the coke works in Ukraine (on the dry ash free basis) is $29-32 \%$, and the mean index of vitrinite reflectance does not exceed $1.0 \%$.

According to the Metallurgprom, Ukraine produces around $18 \mathrm{~m}$ tonnes of coking coals per year, however coke works need at least $29.5 \mathrm{~m}$ tonnes to meet the demand of blast furnace operators. In addition, for the coke production high grade coals are required but some of them are not available in Ukraine. The missing amount is made up with imports, mainly from Russia, in the amount of about $11 \mathrm{~m}$ tpy. However, in Russia due to the growth of metal production, coking coals become more and more scarce, therefore the supplies to Ukraine do not always meet the characteristics required for the production of high quality coke.

Very promising are the imports of high quality coals from abroad (Australia, the USA, Canada). However, for the reception of cargo vessels with coal specifically equipped terminals should be available in Ukrainian ports.
We should also note an unfavorable composition of the mineral part of typical Ukrainian coals and cokes produced from them. The basicity index of the mineral part of the most coals in the Donbass (the ratio of total content of basic sodium, potassium, calcium, magnesium and iron oxides in the ash of coals to total acidic oxides of silicon and amphoteric aluminum) is in the range $0.25-0.35$. At the same time, to obtain coke with the strength after reaction CSR e" $60 \%$ the basicity index must not exceed 0.16 , and for CSR e" $65 \%$ it should be no more than 0.12 provided all the other properties (reflectance, ash, sulphur, volatile matter, etc.) also conform to the requirements to coals shown in Table 1 [3].

In addition, our attention is drawn by rather high carbonizing rates at the coke works in Ukraine. The bulk of coke oven batteries in Ukraine has the width of coking chambers $410 \mathrm{~mm}$, the design carbonizing time $15 \mathrm{hrs}$ that corresponds to a carbonizing rate of $27.3 \mathrm{~mm} / \mathrm{hr}$. Usually coke is obtained, as a rule, at significantly less rates, for example, at the Australian company BHP Steel the carbonizing rate does not exceed $24 \mathrm{~mm} / \mathrm{hr}$. This rate would be equivalent to the carbonizing time $17 \mathrm{hrs}$ in coking chambers of the Giprokoks design of $410 \mathrm{~mm}$ wide [4].

At present there is a clear tendency in the coke industry of Ukraine to use some of the technologies developed earlier for production of coke from poorly caking coals to obtain coke meeting modern requirements by the NSC test and good for blast furnaces with PCI. First of all, these are the technologies of coking of the preheated blend and coking of the stamped blend.

Preheated blend is carbonized in ovens with a useful volume of $21.6 \mathrm{~m}^{3}, 4.3 \mathrm{~m}$ high and $410 \mathrm{~mm}$ wide. The use of preheated blend allows the coke battery output to be increased by $40 \%$.

There is a pilot plant at the JSC Yasinovsky Coke Works for thermal treatment of coal blends of a design capacity of $60 \mathrm{t} / \mathrm{hr}$ of wet coal. The blend is dried and preheated to $200{ }^{\circ} \mathrm{C}$ in two stages by means of rapid heating with a gaseous heat carrier in a stream.

Thermal treatment of coal allowed significant reduction in the cost of coal blend used for coking due to the use of up to $70 \%$ of low rank gas coals. The coke produced is mainly sent to blast furnaces operated without PCI. At present researches are carried out into the production of coke of improved quality from preheated blend for application in blast furnaces with pulverized coal injection.

Stamp charging has been successfully used during a long time (since 1993) on coke oven battery No. 9-bis at the Alchevskkoks [5-6]. In August 2006 battery No. 10 -bis was put into operation where stamp charging was introduced. 


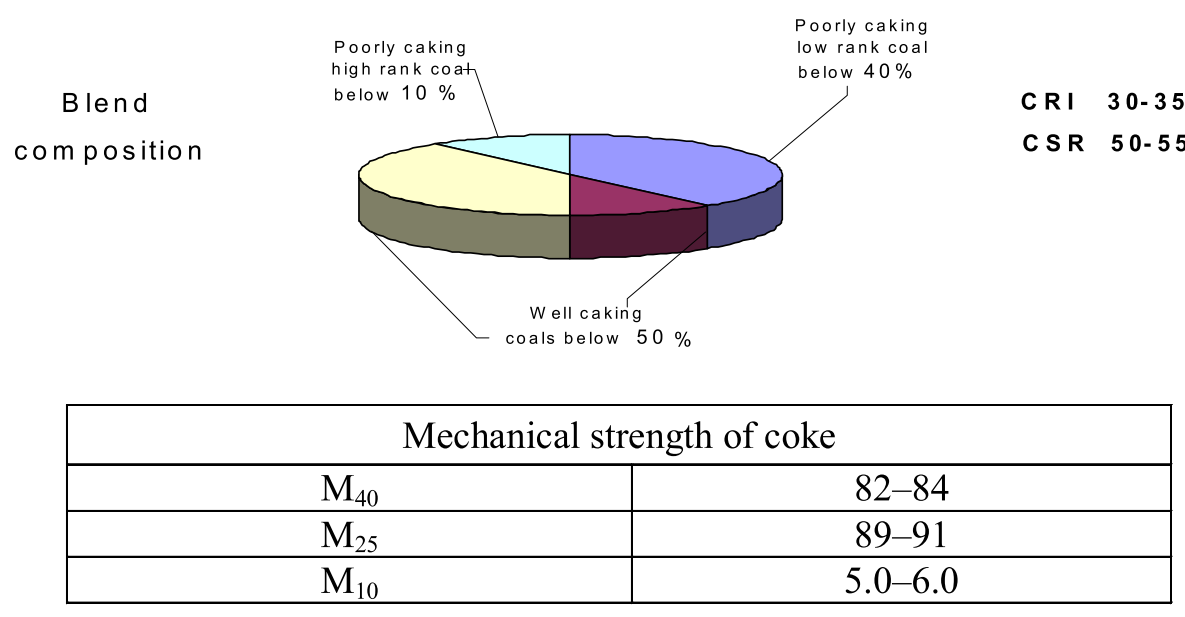

Fig. 3. Coke from preheated blend

Initially the stamping technology as well as preheating was considered mainly as the ways of retaining coke quality due to the cost reduction of blends by using a higher percentage of cheap coals with a lower caking capacity. The blends used for stamping contained a lower amount of fat coals and practically no coking coals. At the time being more actual is a task of improving coke quality. This task is solved by the use of blends with higher caking capacity and higher vitrinite reflectance index.

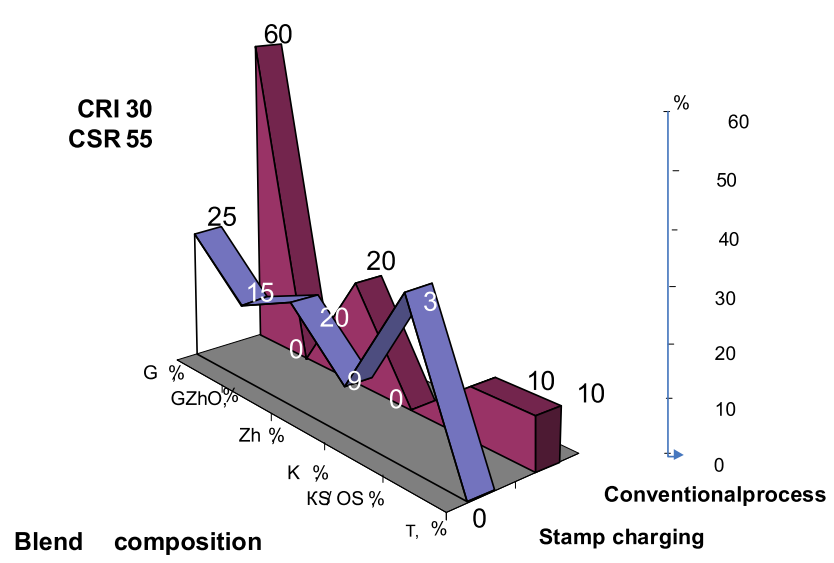

Fig. 4. Coke from stamp blend

Table 2 shows the generalized data on the quality of coke obtained at Ukrainian coke works and used for blast furnace operation with and without pulverized coal injection (PCI) [7].

As is evident from Table 2, coke for blast furnaces without PCI is characterized by inferior reactivity and strength after reaction indices determined by the Nippon Steel method. This coke is also inferior to that of the leading world producers in mechanical strength by the micum test.. Also a higher ash and sulphur of coke calls our attention.
Table 2

Quality of coke at Ukrainian coke works

\begin{tabular}{|l|c|c|}
\hline \multirow{2}{*}{ Indices and units of measure } & \multicolumn{2}{|c|}{ Blast furnace } \\
\cline { 2 - 3 } & $\begin{array}{c}\text { Without } \\
\text { PCI }\end{array}$ & With PCI \\
\hline Reactivity CRI, \% & $35-40$ & $\leq 30$ \\
\hline Strength after reaction CSR, \% & $45-50$ & $\geq 55$ \\
\hline Mechanical strength by micum test, \% & $68-70$ & $\geq 77$ \\
$\mathrm{M}_{40}$ & $7-8$ & $\leq 7.5$ \\
$\mathrm{M}_{10}$ & $\leq 12$ & $\leq 11$ \\
\hline Ash $\mathrm{A}^{\mathrm{d}}, \%$ dry basis & $\leq 1,5$ & $\leq 1$ \\
\hline Total sulphur $\mathrm{S}_{\mathrm{t}}^{\mathrm{d}} \%$ dry basis & $\leq 1$ & $\leq 1$ \\
\hline $\begin{array}{l}\text { Volatile matter } \mathrm{V}^{\text {daf }} \% \text { dry ash free } \\
\text { basis }\end{array}$ & & \\
\hline
\end{tabular}

It should be noted that recently the sulphur content in Ukrainian cokes has decreased significantly (by $0.5-1.0 \%$ ) due to the increasing imports of coking coals with lower sulphur from other countries. This has brought some improvement in the reactivity and strength after reaction of coke. But it is not possible to ensure that the level of these indices will meet the requirements of the leading world producers of iron, because due to the shortage of coking coals in our main suppliers (first of all in Russia) the coal imported to Ukraine is characterized by insufficient reflectance index of vitrinite and frequently by unfavorable chemical composition of ash.

On the whole, the quality of coke for blast furnaces without PCI corresponds to the requirements showing a rather low specific coke rate for producing hot metal $508.5 \mathrm{~kg} / \mathrm{t}$. Technological possibilities of improvement of coke rate in the blast furnace without PCI are nearing their exhaustion. This index was reducing during 19952004 on average over Ukraine by $10-15 \mathrm{~kg} / \mathrm{t}$ annually; since 2005 it was stabilized. 
In order to keep the competitiveness of the Ukrainian metal products on the world market it is necessary to develop iron making technologies by using pulverized coal injection. For the time being there is a single unit of such a type in Ukraine at blast furnace No. 2, JSC Donetsk Metallurgical Plant. Hot metal is produced without using natural gas, the consumption of pulverized fuel has been lately $160-170 \mathrm{~kg} / \mathrm{t}$ of hot metal, that allowed the reduction of coke rate to $390 \mathrm{~kg} / \mathrm{t}$. The coke used in that blast furnace actually completely satisfies the requirements of world standards as is evident from Table 2. This is ensured by using in coal blends high quality coal from some of the Ukrainian coal mines (for example, the Krasnoarmeiskaya Zapadnaya Mine).

Now intensive work is being undertaken to introduce PCI technology in blast furnaces by a number of major
Ukrainian steel producers: Mittal Steel Krivoy Rog, Alchevsk Iron and Steel Plant, Azovstal Iron and Steel Plant, Zaporozhstal Iron and Steel Plant. As is well known PCI requires coke of higher quality. Therefore we should expect in the nearest years a sharp increase in the requirements of the Ukrainian blast-furnace operators to the quality of coke.

The results of two series of blast furnace tests using coke of improved quality under the supervision of specialists of UKHIN are presented in Table 3. The first series was run on blast furnace No. 5 with a useful volume of $1513 \mathrm{~m}^{3}$ [8] at the Azovstal Iron and Steel Plant. The blast furnace does not use PCI, though, as mentioned before, work is being conducted in this direction.

Table 3

Quality of coke for blast furnace tests

\begin{tabular}{|c|c|c|c|c|}
\hline \multirow[t]{2}{*}{ Properties and units of measure } & \multicolumn{2}{|c|}{ Azovstal ISP } & \multicolumn{2}{|c|}{ Donetsk MP } \\
\hline & Base period & Test period & Base period & Test period \\
\hline Actual moisture, Wtr, $\%$ & 4.7 & 4.6 & 4.9 & 4.8 \\
\hline Ash Ad, \% dry basis & 12.2 & 11.6 & 11.0 & 10.4 \\
\hline Total sulphur, Sdt $\%$ dry basis & 1.33 & 1.13 & 1.08 & 0.83 \\
\hline Volatile matter, Vdaf, \% dry ash free basis & 0.9 & 0.9 & 0.9 & 0.8 \\
\hline $\begin{aligned} \text { Mechanical strength in Micum drum, } \% \\
$\[ \mathrm{M}_{25} \]$ \\
\mathrm{M}_{10}\end{aligned}$ & $\begin{array}{c}87.4 \\
8.0\end{array}$ & $\begin{array}{c}87.7 \\
7.1\end{array}$ & $\begin{array}{c}86.6 \\
7.5\end{array}$ & $\begin{array}{c}88.3 \\
6.8\end{array}$ \\
\hline Reactivity CRI, \% & $>35.0$ & 32.3 & 39.6 & 27.9 \\
\hline Strength after reaction CSR, $\%$ & $<50.0$ & 50.0 & 45.7 & 59.1 \\
\hline
\end{tabular}

As is evident from Table 3, coke for blast furnace No. 5 had much better quality than that used traditionally in blast furnaces without PCI.

The quality of blend used to produce coke for blast furnace operation during the base and test periods is shown in Fig. 5.

The use of such coke allowed a significant improvement of the blast furnace operation: its productivity rose by $10.5 \%$, the specific coke rate decreased by 32 $\mathrm{kg} / \mathrm{t}$ hot metal.

These results enabled another series of blast furnace tests on blast furnace No. 2 with a useful volume of $1033 \mathrm{~m}^{3}$ at the JSC Donetsk Metallurgical Plant where PCI is used at the rate $160-170 \mathrm{~kg} / \mathrm{t}$ hot metal. The use of a high quality coke increased the productivity of the blast furnace by $17.1 \%$ and reduced the coke rate by $51 \mathrm{~kg} / \mathrm{t}$ hot metal (Table 4) [7].

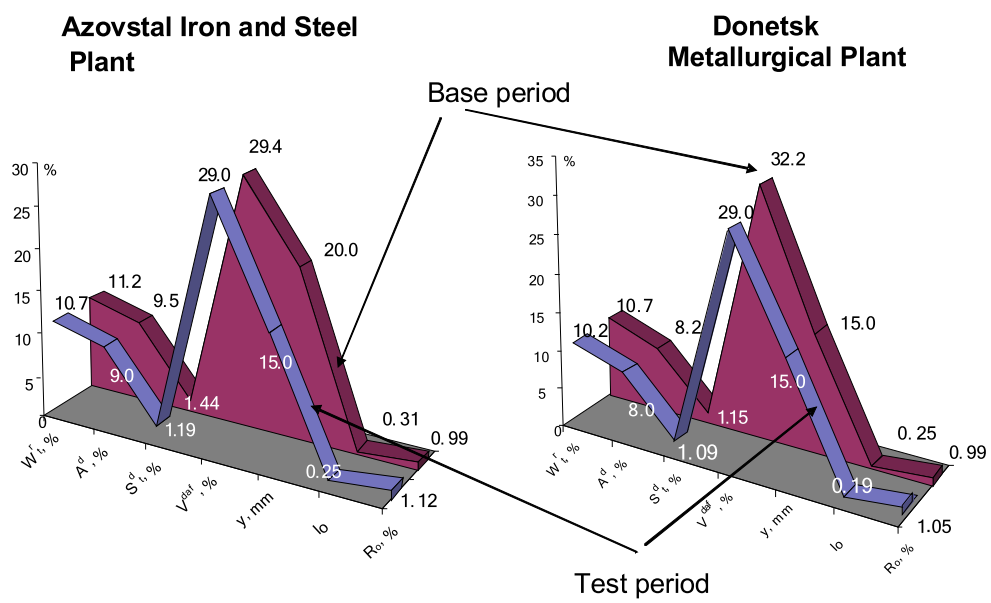

Fig. 5. Coke blend for blast furnace tests 
Results of blast furnace tests

\begin{tabular}{|l|c|c|c|c|}
\hline \multirow{2}{*}{ Parameters } & \multicolumn{2}{c|}{ Azovstal ISP } & \multicolumn{2}{c|}{ Donetsk MP } \\
\cline { 2 - 5 } & Base period & Test period & Base period & Test period \\
\hline Output, $\mathrm{t} /$ day & 2647 & 2924 & 2004 & 2217 \\
\hline Specific coke rate, $\mathrm{kg} / \mathrm{t}$ hot iron & 522 & 490 & 441 & 390 \\
\hline
\end{tabular}

In addition, this coke allowed a number of process parameters to be improved (to raise the air-blast temperature, to eliminate unscheduled down time and slow run of furnace).

The tests done showed the possibility of production of coke from Ukrainian coals in accordance with the requirements of the leading world steel producers. Here the positive effect of upgrading coke quality is significantly higher when using PCI.

That is why UKHIN jointly with the coke works of Ukraine undertakes the work aimed at the improvement of quality of coke. Here we believe that the basis of coke properties lies in its structural characteristics and the main attention should be paid to the production of coke with the required structure.

It is well known that carbon of coke represents a composition of ordered (anisotropic) and disordered (isotropic) carbon. Therefore reactivity of coke is a gross index and it reflects the chemical activity of all the components of the carbon composition when reacting with carbon dioxide.

The reactivity of different types of coke texture is different. The higher total anisotropic carbon in coke and the larger size of anisotropic structures the lower is its reactivity. Fig. 6 illustrates this situation [9].

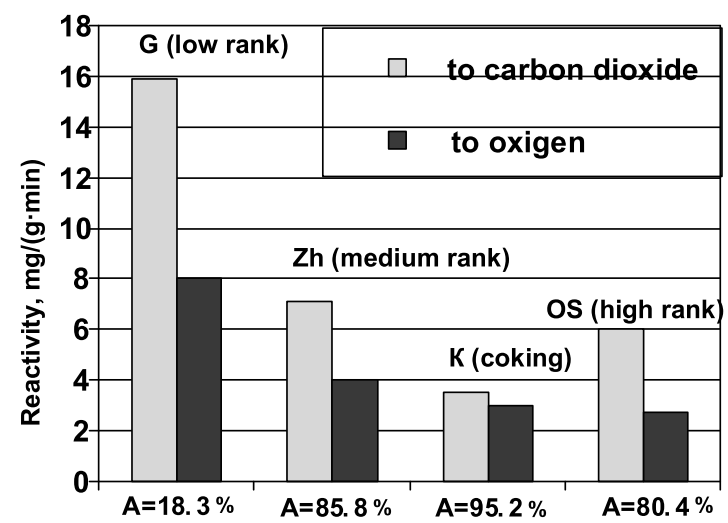

Fig. 6. Dependence of coke reactivity on contents of anisotropic carbon

The results of our tests on model carbon materials showed that the more ordered the carbon structure the lower is its reactivity determined by the Nippon Steel method (Fig. 7).

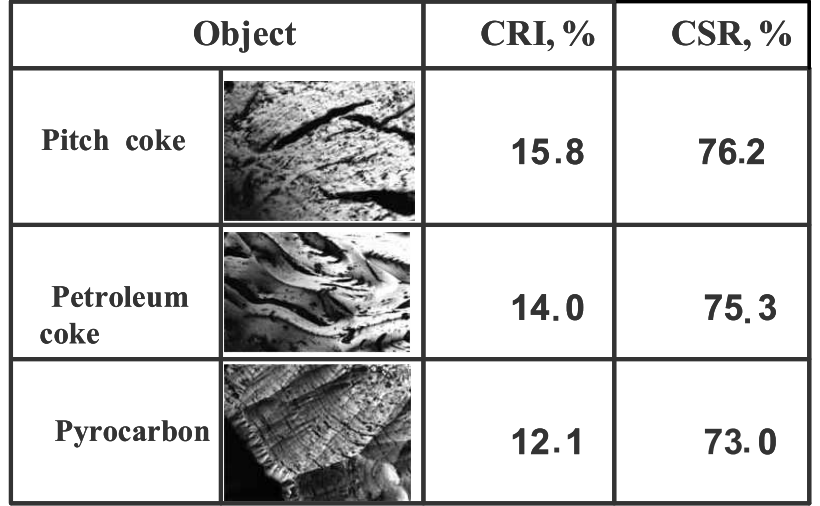

Fig. 7. Reactivity and strength of some carbonaceous materials

Reactions of carbon oxidation proceed with a lower rate in coke with anisotropic structure that allows the coke charge in the blast furnace to retain the required strength and permeability when descending to the low levels of the blast furnace.

In our opinion, blast furnace coke with a predetermined content of anisotropic structures can be produced by using coal blends with the required properties (including the introduction of organic mesogenic additives) and rational technological parameters of carbonization.

\section{Conclusions}

1. Coke production in the future is related not only to the amount of iron produced but also to the improvement of coke quality. The high coke quality will allow both the reduction of coke imports to Ukraine and an increase of the export potential of the coke industry, i.e. this will favor the growth of coke production. At the same time, the improvement in quality of coke will result in a decrease of the coke rate for smelting iron and will decrease a demand for it of metallurgical plants in our country.

2. Coke facilities available in Ukraine are quite enough to completely satisfy the needs of Ukraine in met coke. However, resources and output of coking coals in Ukraine are not sufficient to provide enough raw stock for coke producing facilities. Therefore, in addition to increased mining of domestic coals it is necessary to import coking coals, to introduce the technologies aimed at widening the raw material base for coking and improving the quality of met coke. 
3. The main trends of improving the quality of coke which are developed by Ukrainian scientists and blast furnace and coke oven operators are the following:

3.1. Development of a rational raw material base for coking:

- formation of the required of quality of coal blends for the ash content, sulphur, rank by better washing and reduction of ash in coal concentrates;

- raising of uniformity of coal in terms of its petrographic composition;

- reduction of the sulphur content and raising of coal rank by increasing the output of Ukrainian low sulphur coal and imports of high rank coals;

- addition of organic mesogenic substances and anisotropic materials to the blend.

4. Rational cokemaking technology, that is control of physical and chemical coking processes to transform the isotropic texture of coke to anisotropic one (higher degree of ordering of coke carbon) by reduction of carbonizing rates to the level of no more than $24 \mathrm{~mm} / \mathrm{hr}$, by rational level of final temperatures of carbonization and by additional soaking of coke in coking chambers.

5. Postcarbonization treatment of coke: dry quenching with soaking of coke in the forechamber and additional mechanical treatment of coke to realize mechanical stresses and fissuring.

6. For Ukraine which is lacking in considerable domestic sources of oil and natural gas and dependent on the imports of these power resources the use of chemical and power potential of coking coals is very actual. Therefore there are a lot of chemical divisions at our coke works for processing carbonization by-products. Their final products contribute $40-50 \%$ to the total profit of the coke works. By using coke dry quenching units and by burning excess coke oven gas in heat-and-power plants our coke works can further increase electric power generation.

\section{References}

[1] Rudyka V.I.: Uglekhimichesky Zhurnal, 2006, 5-6, 3.

[2] Miroshnichenko D.V., Bliznyuk T.N. and Toryanik E.V.: Uglekhimichesky Zhurnal, 2003, 5-6, 47.

[3] Leonard D.C., Bonte L., Dufor A. et al.: Coke quality requirements of European blast furnace engeneers. $3^{\text {rd }}$ International Cokemaking Congress. 1996, 1.

[4] Kovalov E.T., Shmalko V.M., Shulga I.V. and Ryschenko A.I.: Uglekhimichesky Zhurnal, 2006, 5-6, 13.

[5] Karpov A.V., Kuznichenko V.M. and Lobov A.A.: Koks i Khimia, 1997, 8, 9.

[6] Chub V.E., Krivonos V.V., Dzikunov S.N. et al.: Koks i Khimia, 2003, 12, 14.

[7] Ryzhenkov A.N., Gordienko A.I., Kovalov E.T. and Shulga I.V.: Requirements to the quality of coke for blast furnace using pulverized fuel and industrial experience of production of this coke. Trudy mezhdunarodnoy nauchno-tekhnicheskoy konferentsii "Pyleugolnoye toplivo - alternativa pryrodnomu gazu pri vyplavke chuguna". 18-21 December 2006, Donetsk, Ukraine.

[8] Buga I.D., Bondarchuk P.I., Ryschenko F.I. et al.: Uglekhimichesky Zhurnal, 2006, 3-4, 47.

[9] Sklyar M.G., Slobodskoy S.A. and Dang V.H.: Koks i Khimia, 1988,3,9.

\section{ВИРОБНИЦТВО І ЯКІСТЬ ДОМЕННОГО КОКСУ В УКРАЇНІ}

Анотація. Надано стан виробництва металургійного коксу в Украӥні. Особлива увага звернена на сировинну базу виробництва коксу та його якість. Зроблено детальний аналіз способів підготовки вугільної шихти для коксування, включаючи термічну підготовку та трамбування шихти. Сформульовано основні шляхи підвищення якості коксу. Розглянуто раціональну технологію коксування.

Ключові слова: вугілля, шихта, доменний кокс, виробництво коксу, термічна підготовка, трамбування шихти, структура коксу, доменні плавки, реакиійна здатність, сухе гасіння коксу 